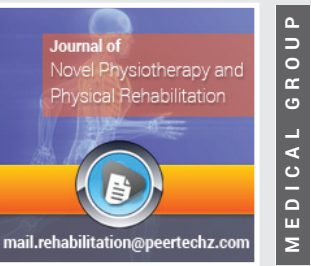

Herman Azanmasso ${ }^{1 *}$, Nada Kyal', Yvette Moigny', Etienne Alagnidé2, Karen Obondzo ${ }^{3}$, Néné Camara ${ }^{3}$, Fatima Lmidmani', Toussaint $\mathbf{G}$ Kpadonou ${ }^{2}$ and Abdellatif El Fatimi'

'Department of Physical and Functional Rehabilitation Medcine of CHU Ibn Rochd of Casablanca, Morocco

${ }^{2}$ Department of Physical and Functional Rehabilitation Medicine of CNHU-HKM of Cotonou, Benin

${ }^{3}$ Department of Neurology of CHU Ibn Rochd of Casablanca, Morocco

Received: 03 September, 2018 Accepted: 30 September, 2019

Published: 01 October, 2019

*Corresponding author: Herman Azanmasso, Department of Physical and Functional Rehabilitation Medcine of CHU Ibn Rochd, Hospital in Casablanca, 1, Rue des Hôpitaux, Casablanca, Morocco, Tel: (00229) 213000 01; Fax: (00229) 21 30 12 88; E-mail: aznower@yahoo.fr

https://www.peertechz.com

Check for updates

\author{
Research Article
}

\section{Sexual dysfunction in multiple}

\section{sclerosis: A prospective monocentric Moroccan study}

\begin{abstract}
Background: Sexuals dysfunctions in multiple sclerosis have been widely described. Their prevalence is estimated at $45 \%-74 \%$ in the female population and $61 \%-91 \%$ in the male population.
\end{abstract}

Objective: To determine the prevalence of sexual dysfunctions in a multiple sclerosis and associates parameters in Casablanca.

Method of study: It was a mono-centric, prospective, descriptive and analytical study on patients suffering from multiple sclerosis followed in neurology of the $\mathrm{CHU}$ Ibn Rochd of Casablanca. The evaluation of sexual dysfunctions was carried out using validated scales, namely the International Index of Erectile Function (IIEF-5) for men and the Female Sexual Function Index (FSFI-6) for women.

Results: The mean age was $37.9 \pm 11.7$ years with an average duration of MS evolution $6.7 \pm 5$ years. Clinical forms were remittent $58.2 \%$, progressive remittent $16.4 \%$ and progressive form $25.4 \%$. The prevalence of sexual dysfunctions estimated with the total of IIEF- 5 was $100 \%$ for sexually active men, with FSFI- 6 of $53.8 \%$ for women and for both sexes $61.1 \%$. The marital status was strongly related to the occurrence of sexual dysfunctions.

Conclusion: Sexuals dysfunctions in multiple sclerosis were common in the sexually active population in Morocco. These dysfunctions were three more likely to occur in men than in women.

\section{Introduction}

Multiple Sclerosis (MS) is a demyelinating disease of the central nervous system that results in the formation of multiple sclerosis plaques. It is a very disabling condition, which generates sensory-motor deficits, disorders of coordination, cognitive disorders as well as urinary disorders, bowel and sexual dysfunctions [1-3]. Sexual disorders in multiple sclerosis have been widely described. Their prevalence is estimated at $45 \%-74 \%$ in the female population and $61 \%-91 \%$ in the male population [3-5]. The characteristics of these sexual dysfunctions were decreased desire, excitement, lubrication, orgasm disorders, sexual satisfaction and dyspareunia in women; Erectile dysfunction, sexual desire, dysejaculation, orgasm and sexual satisfaction in men with multiple sclerosis [6-9]. The causes of these sexual disorders are: first the central lesion itself, second motor disability, muscle contractions and spasticity, third urinary disorders, fatigue and finally depression [7-10]. These disorders are associated with impaired quality of life of patients [7]. The objective of this study was to determine the prevalence of sexual disorders in a population of MS in Casablanca and to identify the parameters associated with sexual disorders.

\section{Method of Study}

\section{Methods}

Type of study: This was a mono-centric, prospective, descriptive and analytical study of all the patients suffering from multiple sclerosis followed in neurology by the CHU Ibn Rochd of Casablanca and whose addresses were communicated for a follow-up and taking care. These patients were called and seen at the Department of Physical Medicine and Functional Rehabilitation of the Ibn Rochd University Hospital of Casablanca, in consultation of neuro-urology from December 2015 to December 2016.

Inclusion criteria: All patients with MS, followed in neurology by the Ibn Rochd University Hospital of Casablanca, were included in this study for their follow-up and neurourology management in the Department of Physical Medicine and Functional Rehabilitation. 
Non-inclusion criteria: All MS patients who have suffered or have a neurological disorder (stroke, cerebral abscess, brain and, or medullary tumors, peripheral neuropathy) or urogynecological (prolapse, prostatic hypertrophy, pelvic tumors) that can cause sexual dysfunctions were excluded from this analysis.

Conduct of the study: The patient list obtained from the CHU Neurology department allowed us to contact a total of 83 patients. Seventeen patients lived far from Casablanca, very handicapped by the pathology, did not have the capacity to move easily. Four patients had died and 7 patients had never answered to our calls or were not at the many appointments. At the neuro-urological consultation, an interrogation and a physical examination made it possible to establish a medical file for the follow-up of each patient. Ages, sex, marital status, occupation, history, duration of development, mode of commencement, type of deficit were collected. The evaluation of sexual dysfunctions was carried out using validated scales, namely the International Index of Erectile Function (IIEF-5) for men and the Female Sexual Function Index (FSFI-6) for women, Expanded Disability Status Scale (EDSS), the Urinary Symptom Symptom (USP) and the Neurogenic Bowel Disorder Scale were systematically administered to all patients. For each parameter of the FSFI- 6 and IIEF- 5 questionnaires, a rating of greater than or equal to 4 was considered to be an absence of dysfunction. Thus, for the prevalence of sexual disorders was determined as follows: IIEF- $5<20$ assert the existence of sexual dysfunction similarly for FSFI- $6<24$.

Bowel dysfunction (constipation) and urinary disorders (incontinence, owerbladder activity) were asked.

\section{Statistical analysis of data}

The data were collected and analyzed using the Epi Info 2007 software. The comparison between qualitative and quantitative variables was with the ANOVA parametric test. The threshold of statistical significance was below $5 \%$.

\section{Ethical considerations}

This analysis had obtained the oral informed consent of the patients. Respect for confidentiality, anonymity and medical confidentiality had been strict during this study. Ethical committee approval was obtained.

\section{Results}

\section{Socio-epidemiological, clinical and therapeutic charac- teristics}

The mean age was $37.9 \pm 11.7$ years with an average duration of MS evolution $6.7 \pm 5$ years. In terms of marital status, patients were distributed as follows: $47.3 \%$ married, $41.8 \%$ single, 4 divorced and 2 widowed.

The medical history was fund in $14.5 \%$ with high blood pressure $(5.4 \%)$ and others $(9.1 \%)$. The surgical history was fund in $18.2 \%$ with Caesarean sections $(7.3 \%)$, digestive surgery $(5.4 \%)$ and others (5.4\%).
The initial mode was a hemiparesia $27.7 \%$, paraparesia $17 \%$, monoparesia $25.5 \%$, retrobulbar optic neuritis $23.4 \%$. Sociodemographic and clinical data are presented in Table 1.

The quality of patient sexuality was characterized by normal sexual activity $12.7 \%$, sexual inactivity $65.5 \%$ and sexual dysfunction $21.8 \%$ (Table 1). Data on the distribution of patients by type of sexual dysfunction in the multiple sclerosis

\begin{tabular}{|c|c|c|c|}
\hline & $\mathbf{N}$ & $\%$ & Average and Median \\
\hline Age (year) & 55 & & $37.9 \pm 11.736$ \\
\hline Sex (ratio) & $0.491 \mathrm{H} / 2 \mathrm{~F}$ & & \\
\hline - Male & 18 & 32.7 & \\
\hline - Female & 37 & 67.3 & \\
\hline \multicolumn{4}{|l|}{ Profession } \\
\hline - Housewife & 28 & 50.9 & \\
\hline - Student & 3 & 5.5 & \\
\hline - Artisans & 3 & 5.5 & \\
\hline - Trading & 2 & 3.6 & \\
\hline - Official & 3 & 5.5 & \\
\hline - Without work & 16 & 29.1 & \\
\hline \multicolumn{4}{|l|}{ Marital status } \\
\hline - Single & 23 & 41.8 & \\
\hline - Divorced & 4 & 7.2 & \\
\hline - Widow & 2 & 3.6 & \\
\hline - Married & 26 & 47.3 & \\
\hline \multicolumn{4}{|l|}{ Clinical forms } \\
\hline - MS-PP & 14 & 25.4 & \\
\hline - MS-RP & 9 & 16.4 & \\
\hline - MS-RR & 32 & 58.2 & \\
\hline Duration of evolution (year) & & & $6.7 \pm 55$ \\
\hline$[0 ; 5]$ & 26 & 47.3 & \\
\hline$[5 ; 10]$ & 17 & 30.9 & \\
\hline$[10 ; 26]$ & 12 & 21.8 & \\
\hline EDSS & & & $4.8 \pm 2.36$ \\
\hline$[0 ; 3]$ & 16 & 29.1 & \\
\hline$] 3 ; 6]$ & 25 & 45.5 & \\
\hline$] 6 ; 8.5]$ & 14 & 25.5 & \\
\hline \multicolumn{4}{|l|}{ Clinical data } \\
\hline - Moteur deficit & 41 & 74.5 & \\
\hline - Sensory deficit & 29 & 52.7 & \\
\hline - Cognitive impairment & 33 & 60 & \\
\hline \multicolumn{4}{|l|}{ Sexual disorders } \\
\hline - Sexual dysfunction & 12 & 21.8 & \\
\hline - Sexual inactivity & 36 & 65.5 & \\
\hline - Normal sexual activity & 7 & 12.7 & \\
\hline
\end{tabular}

MS-PP: Progressive form MS-RP: Remittente progressive form MS-RR: Remittente form EDSS: Expanded Disability Status Scale 
population are presented in Table 2 . The prevalence of sexual dysfunction estimated with the total of IIEF- 5 was $100 \%$ for sexually active men, with FSFI- 6 of $53.8 \%$ for women and for both sexes $61.1 \%$. Table 3 presents the parameters associated with sexual dysfunction in multiple sclerosis. The risk of sexual dysfunction and sexual inactivity increased three-fold for men, while marital status was strongly related to the occurrence of sexual dysfunction and sexual inactivity.

Bowel dysfunction (constipation) and urinary disorders (incontinence, owerbladder activity) were found in $76.9 \%$ and $84.6 \%$ respectively, without influencing the sexual dysfunction respectively $\mathrm{p}=0.9$ and 0.5 .

\section{Discussion}

Sexual dysfunction is common in multiple sclerosis [3-9]. These disorders include decreased libido, sexual inactivity, disorders of lubrication and orgasm in women and disorders of erection and ejaculation in men [6-9,11]. One observation is unanimously reported that these dysfunctions are little sought after by the healthcare teams, even though they exist even outside of an important functional handicap $[6,7,9,11]$. The literature is rich in Moroccan data on the epidemiology, genetics, clinical, therapeutics and quality of life of patients suffering from MS [12-16]. No studies to day on the prevalence and management of sexual dysfunction in this population in Morocco. In Tunisia Ghroubi and al. had found a prevalence of $46.9 \%$ with $70 \%$ for men and $34 \%$ for women [17]. As noted by the authors, this prevalence remains one of the lowest in the literature $[3-9,17,18]$. In our series, the prevalence was $100 \%$ for men and $53.8 \%$ for women with $76.9 \%$ decline in libido in the female population Table 2 . This prevalence is very high in comparison with that reported in Tunisia [17], whereas these two Muslim societies have the same socio-familial and religious realities. The proportions observed in the literature [7,19-22], are comparable to those found in our analysis in both

Table 2: Distribution of Patients by Sexual dysfunction types in the Multiple Sclerosis Population.

\begin{tabular}{|c|c|c|c|}
\hline & N & $\%$ & Average Median \\
\hline Desire & Women & & \\
\hline Sexual excitation & 10 & 76.9 & $2 \pm 13$ \\
\hline Lubrification & 7 & 53.8 & $2.9 \pm 1.23$ \\
\hline Orgasm & 3 & 23.1 & $3.9 \pm 1.75$ \\
\hline Sexual satisfaction & 5 & 38.5 & $3.5 \pm 1.84$ \\
\hline Dyspareunia & 6 & 46.2 & $3.2 \pm 1.54$ \\
\hline Sexual inactivity & 7 & 53.8 & $2.8 \pm 23$ \\
\hline & 5 & 27.8 & \\
\hline Erection dysfunction & 4 & 80 & $3 \pm 0.73$ \\
\hline Penile stiffness disorder & 6 & 100 & $3.4 \pm 0.54$ \\
\hline dysejaculation & 4 & 80 & $3 \pm 0.73$ \\
\hline Desire & 4 & 80 & $3.2 \pm 0.43$ \\
\hline Sexual satisfaction & 2 & 40 & $3.6 \pm 0.54$ \\
\hline Sexual inactivity & 3 & 37.5 & \\
\hline
\end{tabular}

Table 3: Distribution of Patients by Parameters Associated with Sexual Disorders.

\begin{tabular}{|c|c|c|c|}
\hline & Sexual & dysfunction & \\
\hline & $\mathrm{N}$ & $\%$ & Statistic tests \\
\hline & Sexual inactivity & Sexual dysfunction & \\
\hline Single & 2295.7 & 14.3 & $\mathrm{Chi}^{2}=26.4$ \\
\hline Divorced & 4100 & -- & $\mathrm{Ddl}=6$ \\
\hline Widow & 2100 & -- & $p=0.0002$ \\
\hline \multirow[t]{2}{*}{ Married } & 830.8 & 1142.3 & \\
\hline & Age & & \\
\hline Inactivity & 8 & 30.8 & $49.5 \pm 10.3 p=0.1$ \\
\hline Normal sexuality & 7 & 26.9 & $39.9 \pm 9.2$ \\
\hline \multirow[t]{2}{*}{ Sexual dysfunction } & 11 & 42.3 & $39.5 \pm 11.6$ \\
\hline & EDSS & & \\
\hline Inactivity & 8 & 30.8 & $5 \pm 2.9 p=0.3$ \\
\hline Normal sexuality & 7 & 26.9 & $3.6 \pm 2.4$ \\
\hline \multirow[t]{2}{*}{ Sexual dysfunction } & 11 & 42.3 & $5.3 \pm 2$ \\
\hline & Evolution & & \\
\hline Inactivity & 8 & 30.8 & $7.8 \pm 5.5 p=0.6$ \\
\hline Normal sexuality & 7 & 26.9 & $9 \pm 3$ \\
\hline Sexual dysfunction & 11 & 42.3 & $7.2 \pm 4.4$ \\
\hline Sex & Inactivity & Sexual dysfunction & \\
\hline Male & 337.5 & 562.5 & Odds ratio $=3.1$ \\
\hline Female & 527.8 & 633.3 & $95 \% \operatorname{IC}[0.3 ; 28] p=0.3$ \\
\hline Formes cliniques & Inactivity & Sexual dysfunction & \\
\hline MS-PP & 337.5 & 450 & $\mathrm{Chi}^{2}=4.8 \mathrm{ddl}=4$ \\
\hline MS-RP & -- & 240 & $p=0.3$ \\
\hline \multirow[t]{2}{*}{ MS-RR } & 538.5 & 538.5 & \\
\hline & Inactivity & Sexual dysfunction & \\
\hline Moteur deficit & 838.1 & 942.9 & $\mathrm{Chi}^{2}=4.4 \mathrm{ddl}=2 \mathrm{p}=0.1$ \\
\hline Sensory deficit & 325 & 541.5 & $\mathrm{Chi}^{2}=0.6 \mathrm{ddl}=2 \mathrm{p}=0.7$ \\
\hline Cognitive deficit & 533.3 & 640 & $\mathrm{Chi}^{2}=0.1 \mathrm{ddl}=2 \mathrm{p}=0.9$ \\
\hline
\end{tabular}

sexes Tables 4,5. Sexual inactivity in multiple sclerosis victims is observed in nearly one-third of men and little than onethird among women $[7,17,19]$. Sexual inactivity is the result of physical manifestations and sensory-motor deficit [11].

In our study, the age, sex, duration of progression of multiple sclerosis, clinical form, EDSS, motor deficit, sensory or cognitive, bowel dysfunction and urinary disorders were not statistically related to the presence of sexual dysfunction Table 3. Nevertheless, marital status was strongly associated with sexual disorders $\mathrm{p}=0.0002$. Moreover, the male sex multiplies by 3 the risk of sexual dysfunction $[17,19]$. Physical, psychosocial, cultural and emotional parameters were reported to be important in the development of sexual dysfunction [711]. Similarly, significant hormonal alteration was associated with sexually unrelated disorders [22].

This study allowed us to take stock of the importance of these disorders in order to allow the caregivers to systematically search for them in order to improve the quality of life of patients $[11,17,19,22]$. The limit of this analysis is the size of 
Table 4: Prevalence of Sexual Dysfunction in men

\begin{tabular}{|c|c|c|c|c|c|c|}
\hline & Erection (\%) & Stiffness (\%) & Ejaculation (\%) & Desire (\%) & Satisfaction (\%) & Inactivity (\%) \\
\hline Our study, 2016, Marocco & 80 & 100 & 80 & 80 & 40 & 37.5 \\
\hline Ghroubi, 2015, Tunisia [17] & 91.7 & - & 50 & 50 & 50 & 41.7 \\
\hline Lew-Starowicz, 2014, Poland [9] & 40.5 & 54.6 & 17.9 & 26.8 & 43.1 & - \\
\hline Tepavcevic, 2008, Serbia [19] & 74.2 & 32.6 & 77.8 & 54.8 & - & 3.2 \\
\hline Nortvedt, 2007, Norway [20] & 85.7 & - & 53.8 & 69.2 & 54.5 & - \\
\hline Demirkiran, 2006, Turkey [21] & 72.2 & 64.7 & - & 63.6 & 52.9 & - \\
\hline
\end{tabular}

Table 5: Prevalence of Sexual Dysfunction in Women.

\begin{tabular}{|c|c|c|c|c|c|c|c|}
\hline & Desire (\%) & Excitation (\%) & Lubrification (\%) & Orgasm (\%) & Satisfaction (\%) & Pain (\%) & Inactivity (\%) \\
\hline Our study, 2016, Marocco & 76.9 & 53.8 & 23.1 & 38.5 & 46.2 & 53.8 & 27.8 \\
\hline Ghroubi, 2015 Tunisia [17] & 54.5 & - & 27.3 & 73 & - & 27.3 & 27.3 \\
\hline Lew-Starowicz, 2013, Poland [7] & 57.7 & 45.2 & 48.4 & 39.8 & 43.1 & - & 29.9 \\
\hline Lombardi, 2011 , Italy [22] & 38.7 & 29 & 29 & 19.4 & 100 & 3.2 & - \\
\hline Tepavcevic, 2008, Serbia [19] & 74.4 & 26.9 & 38.5 & 60.3 & - & - & 15.5 \\
\hline Nortvedt, 2007, Norway [20] & 55.9 & 50 & 41.2 & 64.7 & 35.3 & - & - \\
\hline Demirkiran, 2006, Turkey [21] & 63.6 & 60.5 & 51.5 & 66.7 & 68.3 & - & - \\
\hline
\end{tabular}

our sample. This population is constantly increasing and this will allow for more interesting analyzes later.

\section{Conclusion}

Sexual disorders in multiple sclerosis were common in the sexually active population in Morocco. These disorders were three more likely to occur in men than in women. Many factors such as age, sex, deficiency, EDSS, duration of disease, Bowel dysfunction and urinary disorders were not related to sexual disorders. It would have been interesting to do a quantified analysis of depression and anxiety and their treatment in order to assess the impact on the onset of sexual dysfunction.

\section{References}

1. Pugliatti M, Rosati G, Carton H, Riise T, Drulovic J, et al. (2006) The epidemiology of multiple sclerosis in Europe. Eur J Neurol 13: 700-722. Link: http://bit.ly/2muaflr

2. Ghezzi A, Carone R, Del Popolo G, Amato MP, Bertolotto A, et al. (2011) Recommendations for the management of urinary disorders in multiple sclerosis: a consensus of the Italian Multiple Sclerosis Study Grou. Neurol Sci 32: 1223-1231. Link: http://bit.ly/2mwHKnl

3. Ghezzi A (1998) Sexual dysfunction in multiple sclerosis. Int MS J 5: 45-53.

4. Zorzon M, Zivadinov R, Bosco A, Bragadin LM, Moretti R, et al. (1999) Sexual dysfunction in multiple sclerosis: A case-control study. I. Frequency and comparison of groups. Mult Scler 6: 418-427. Link: http://bit.ly/2muclMJ

5. Schmidt EZ, Hofmann P, Niederwieser G, Kapfhammer HP, Bonelli RM (2005) Sexuality in multiple sclerosis. J Neural Transm 112: 1201-1211. Link: http://bit.ly/2nmizEa

6. Lew-Starowicz M, Rola R (2013) Prevalence of sexual dysfunctions among women with multiple sclerosis. Sex Disabil 31: 141-153. Link: http://bit.ly/2myWXUW

7. Lew-Starowicz M, Rola R (2014) Correlates of sexual function in male and female patients with multiple sclerosis. J Sex Med 11: 2172-2180. Link: http://bit.ly/2nliDUH
8. Gruenwald I, Vardi Y, Gartman I, Juven E, Sprecher E, et al. (2007) Sexua dysfunction in females with multiple sclerosis: quantitative sensory testing. Mult Scler 13: 95-105. Link: http://bit.ly/2oOysUl

9. Lew-Starowicz M, Rola R (2014) Sexual dysfunctions and sexual quality of life in men with multiple sclerosis. J Sex Med 11: 1294-1301. Link: http://bit.ly/2o4pEt8

10. Kessler TM, Fowler CJ, Panicker JN (2009) Sexual dysfunction in multiple sclerosis. Expert Rev Neurother 9: 341-350. Link: http://bit.ly/2oLSHly

11. Bronner G, Elran E, Golomb J, Korczyn AD (2010) Female sexuality in multiple sclerosis: the multidimensional nature of the problem and the intervention. Acta Neurol Scand 121: 289-301. Link: http://bit.ly/2oa81YP

12. Araqi-Houssaini A, Lahlou I, Benkadmir Y, El Otmani H, Hajjaj I, et al. (2014) Multiple sclerosis severity score in a cohort of Moroccan patients. Mult Scler 20: 764-765. Link: http://bit.ly/2o46SSR

13. Araqi-Houssaini A, Dany F, Sekkat Z, Camara NA, Hazim A, et al. (2014) Pediatric multiple sclerosis: Is it different from adult form? Rev Neurol 170 531-535. Link: http://bit.ly/2oLUsiE

14. Ait Ben Haddou E, Alhyan M, Aasfara J, Regragui W, Ibrahimi A, et al. (2014) Multiple sclerosis: clinical characteristics and disability progression in Moroccan children. J Neurol Sci 346: 128-132. Link: http://bit.ly/2o7oQ6I

15. El Alaoui Taoussi K, Ait Ben Haddou E, Benomar A, Abouqal R, Yahyaoui M (2012) Quality of life and multiple sclerosis: Arabic language translation and transcultural adaptation of "MSQOL-54" Rev Neurol 168: 444-449. Link: http://bit.ly/2o47Hep

16. Ouadghiri S, El Alaoui Toussi K, Brick C, Ait Benhaddou EH, Benseffaj N, et al. (2013) Genetic factors and multiple sclerosis in the Moroccan population: a role for HLA class II. Pathol Biol 61: 259-263. Link: http://bit.ly/2n7hTTj

17. Ghroubi S, Elleuch W, Chaabouni A, Yaich S, Elleuch MH (2015) Troubles sexuels chez les patients atteints de sclérose en plaques: À propos d'une population tunisienne. Sexol 24: 176-182. Link: http://bit.ly/2oQvFtV

18. de Sèze M, Gamé X (2014) Sclérose en plaques et pelvipérinéologie: Troubles vésico-sphinctériens, sexuels et maternité. Progrès en Urologie 24: 483-494. Link: http://bit.ly/2nnbljt

19. Tepavcevic DK, Kostic J, Basuroski ID, Stojsavljevic N, Pekmezovic T, et al. 
(2008) The impact of sexual dysfunction on the quality of life measured by MSQoL-54 in patients with multiple sclerosis. Mult Scler 14: 1131-1136. Link: http://bit.ly/2o8CeHG

20. Nortvedt MW, Riise T, Frugârd J, Mohn J, Bakke A, et al. (2007) Prevalence of bladder, bowel and sexual problems among multiple sclerosis patients two to five years after diagnosis. Mult Scler 13: 106-112. Link: http://bit.ly/2oQxBmb
21. Demirkiran M, Sarica Y, Uguz S, Yerdelen D, Aslan K (2006) Multiple sclerosis patients with and without sexual dysfunction: are there any differences? Mult Scler 12: 209-214. Link: http://bit.ly/2nlig0R

22. Lombardi G, Celso M, Bartelli M, Cilotti A, Del Popolo G (2011) Female sexual dysfunction and hormonal status in multiple sclerosis patients. J Sex Med 8 1138-1146. Link: http://bit.ly/2nli90R

\section{Discover a bigger Impact and Visibility of your article publication with} Peertechz Publications

\section{Highlights}

* Signatory publisher of ORCID

* Signatory Publisher of DORA (San Francisco Declaration on Research Assessment)

* Articles archived in worlds' renowned service providers such as Portico, CNKI, AGRIS, TDNet, Base (Bielefeld University Library), CrossRef, Scilit, J-Gate etc.

* Journals indexed in ICMJE, SHERPA/ROMEO, Google Scholar etc.

* OAI-PMH (Open Archives Initiative Protocol for Metadata Harvesting)

* Dedicated Editorial Board for every journal

* Accurate and rapid peer-review process

* Increased citations of published articles through promotions

* Reduced timeline for article publication

Submit your articles and experience a new surge in publication services (https://www.peertechz.com/submission).

Peertechz journals wishes everlasting success in your every endeavours.

作 use, distribution, and reproduction in any medium, provided the original author and source are credited. 